\title{
THE 'GREAT GAME’ OF SOVEREIGN DEBT RESTRUCTURING: SOLVING THE HOLDOUT PROBLEM. A CRITICAL ANALYSIS OF THE PARI PASSU AND COLLECTIVE ACTION CLAUSES IN INTERNATIONAL SOVEREIGN BOND CONTRACTS
}

\author{
Akshay S. Gohil
}

\begin{abstract}
This paper critically evaluates the law of sovereign debt restructuring pertaining to the regulation of creditor co-ordination and holdout creditors. More precisely, it provides a detailed examination and analysis of two important non-financial clauses in sovereign bond documentation: the 'collective action clause' (CAC) and the 'pari passu clause'. It leads with one research question: does the pari passu clause and CAC adequately address the holdout problem and encourage the orderly restructuring of sovereign debt? It also provides independent judgment as how best to improve this area of law. Overall, this paper argues that the clauses, albeit not a panacea, both reflect an impressive collaborative effort between private and public sectors and mitigate holdout leverage
\end{abstract}

\section{A. INTRODUCTION}

Sovereign debt restructuring is back on the agenda after two recent occurrences: Argentina's intent to restructure $\$ 68.8$ billion in foreign-law bonds ${ }^{1}$ and Lebanon's default on $\$ 1.2 \mathrm{bn}$ debt. $^{2}$ Both cases remain exposed to the potential mischief of holdout creditors: this is the process where vulture (hedge) funds seek full repayment of their original bonds through litigation, as opposed to participating in debt negotiations. Finding ways to minimise holdout behaviour represents the 'Great Game' ${ }^{3}$ of academics and practitioners in this field, dubbed 'the most difficult of all the arenas of law'. 4

\footnotetext{
* LL.B., LL.M. (International Commercial Law). I am indebted to Professor Graham Penn for extending my interest beyond corporate insolvency and into the world of sovereign debt restructuring -an area apparently reserved for a 'small but committed contingent of pointy heads'. His passion and dedication to my progress has contributed to the pages which follow. I also thank Yiannis Bazinas for his valuable comments, as well as my family for their helpful critique along the way. Any errors, omissions and opinions are mine alone.

${ }^{1}$ Adam Jourdan and Rodrigo Campos, 'Exclusive: Argentina to Unveil Debt Restructuring "Guideposts" this Week, no Formal Offer yet for Creditors' (30 March 2020) <https://www.reuters.com/article/us-argentina-debtexclusive/argentina-to-unveil-debt-restructuring-guideposts-this-week-no-formal-offer-yet-for-creditors-sourceidUSKBN21H2GD?il=0> accessed 10 April 2020.

${ }^{2}$ Chloe Cornish and Tommy Stubbington, 'Lebanon to Default on \$1.2bn Debt' Financial Times (London, 7 March 2020) <https://www.ft.com/content/951a6386-6097-11ea-a6cd-df28cc3c6a68> accessed 10 April 2020.

3 John Crabb, 'Q\&A with Sovereign Debt Legend Lee Buchheit', International Financial Law Review (23 April 2019) < https://www.iflr.com/Article/3866554/Q-A-with-sovereign-debt-legend-Lee-Buchheit.html> accessed 10 April 2020.

${ }^{4}$ Lee Buchheit and Mitu Gulati, 'Deterring Holdout Creditors in a Restructuring of PDVSA Bonds and Promissory Notes' (2018) 13(2) Capital Markets Law Journal 148; Philip Wood and others, 'Sovereign Bankruptcy Study Group' (Johannesburg 7-11 August 2016) 2.

(C) 2020, The Authors. This is an open access article distributed under the terms of the Creative Commons Attribution License (CC BY) 4.0 https://creativecommons.org/licenses/by/4.0/, which permits unrestricted use, distribution and reproduction in any medium, provided the original author and source are credited - DOI: https://doi.org/10.14324/111.2052-1871.125.
} 
The wider implications of holdout behaviour must not be understated. Holdout activity can inhibit the ability of the sovereign debtor to raise capital in the international capital markets and pay existing bondholders. ${ }^{5}$ Such obdurate behaviour can perpetrate the sense of crisis for years and sometimes even for decades, resulting in frozen credit markets, unavailable trade finance, endemic capital flight, chronic instability in the financial sector and withered foreign direct investment. ${ }^{6}$ The ability of holdouts to block a restructuring can also lead to a disorderly default and lead to holdouts receiving more favourable rates than majority bondholders: this gives rise to an inter-creditor equity problem. ${ }^{7}$

Addressing the collective action problem and promoting effective coordination and engagement in the sovereign debt restructuring process is one of the highest priorities for a sovereign debt restructurer. ${ }^{8}$ The latest reforms to the sovereign bond documentation have been hailed as intrinsic to overcoming the holdout problem: the enhanced CACs create optionality for sovereign debtors vis-à-vis bondholder voting procedures and the new version of the pari passu clause seeks to nullify the precedential value of $N M L .{ }^{9}$

Through an examination of the market's (efficient) responses to sovereign debt contracts, I will judge the extent to which the reformed CACs provide flexibility to sovereign debtors, protect creditor rights and encourage creditor coordination. I will also provide independent judgment as to whether these clauses address the holdout problem in practice and may deservedly earn the title of being, as practitioners opine, 'the most successful publicprivate collaboration in respect of sovereign debt in the past decade'. ${ }^{10}$

The scope of this paper is deliberately limited to two aspects. First, an evaluation of the pari passu clause and CACs in sovereign debt contracts and second, exploring possible solutions vis-à-vis the future of sovereign debt workouts. The latter is important given the lack

\footnotetext{
${ }^{5}$ Allen \& Overy Global Law Intelligence Unit, 'How the Greek Debt Reorganisation of 2012 Changed the Rules of Sovereign Insolvency’ (September 2012) 32.

${ }^{6}$ Christoph Trebesch and Michael Zabel, 'The Output Costs of Hard and Soft Sovereign Default' (2017) 92(c) European Economic Review 416, 417-8; Lee Buchheit and others, 'The Sovereign Debt Restructuring Process' (4 September 2018) 15.

${ }^{7}$ Christoph Steffen, Sebastian Grund and Julian Schumacher, 'Collective Action Clauses in the Euro Area: A Law and Economic Analysis of the First Five Years' (2019) 14(2) Capital Markets Law Journal 134, 144.

${ }^{8}$ Rosa M Lastra and Lee Buchheit, Sovereign Debt Management (1st edn, OUP 2014) 5.

${ }^{9}$ Republic of Argentina $v$ NML Capital, Ltd, 573 US 134 (2014). See also James M Blakemore and Michael J Lockman, 'Pari Passu Undone: Game-Changing Decisions for Sovereigns in Distress' (2017) 3 Emerging Markets Restructuring Journal.

${ }^{10}$ Deborah Zandstra, 'New Aggregated Collective Action Clauses and Evolution in the Restructuring of Sovereign Debt Securities' (2017) 12(2) Capital Markets Law Journal 180, 203.
} 
of consensus on how to reform the international financial architecture. ${ }^{11}$ This paper addresses the first aspect by arguing that the enhanced contractual provisions, albeit not a panacea, effectively mitigate holdout leverage. On the issue of reform, it argues that incremental steps towards an improved international framework are important in promoting efficient sovereign debt workouts.

This paper is structured as follows: Section B examines the market conditions preceding reforms to sovereign debt contracts to provide contextual understanding of how the market functioned and evolved over time. Section C diagnoses the legal aspects of debt reimbursement vis-à-vis vulture funds and 'recalcitrant' creditors. Within this, it evaluates prominent holdout litigation and the controversial 'rateable' interpretation of the pari passu clause. This is important insofar as a broad (rateable) interpretation can impair a restructuring and harm developing nations. ${ }^{12}$ Section D embarks upon a two-part analysis of CACs: the first part examines CACs in the Eurozone and the second analyses the menu of bondholder voting procedures granted to the sovereign. Finally, Section E offers the writer's opinion as to what is the best solution moving forward; the issues discussed will be drawn together to present a conclusive summary of whether the law has struck a balance between preserving creditor rights and diminishing recalcitrant creditor leverage that can obstruct a sovereign debt restructuring. ${ }^{13}$

\section{B. HISTORICAL BACKGROUND}

Before examining prominent holdout litigation and the contractual tools addressing the holdout dilemma, it is necessary to first explore the market conditions prior to the sovereign bond reforms to understand how and why the current law on sovereign debt restructuring materialised. This section argues that the issuance of Brady bonds resulted in a diversification of market participants and the emergence of a new investor class (holdouts) eager to profit. ${ }^{14}$

\section{The Holdout Strategy}

Upon an event of default, a sovereign debtor will lack the resources to pay all of its debts on their original terms and will seek to negotiate with creditors to restructure its debt obligations

\footnotetext{
${ }^{11}$ Faisal Z Ahmed and Laura Alfaro, 'Market Reactions to Sovereign Litigation' (2017) 12(2) Capital Markets Law Journal 141, 158.

${ }^{12}$ Republic of Argentina v NML Capital, Ltd, 573 US 134 (2014), Brief of Joseph Stiglitz as Amicus Curiae in Support of $\quad$ Petitioner $\quad(24 \quad$ March $\quad 2014) \quad 1$ $<$ https://www8.gsb.columbia.edu/faculty/jstiglitz/sites/jstiglitz/files/Argentina_Stiglitz_Amicus.pdf $>$ accessed 7 July 2020.

${ }^{13}$ ibid 12; Jill E Fisch and Caroline M Gentile, 'Vultures or Vanguards?: The Role of Litigation in Sovereign Debt Restructuring' (2004) 53 Emory Law Journal 1047.

${ }^{14}$ For Brady bonds see Section B. 2. below.
} 
through an exchange offer. ${ }^{15}$ This presents an opportunity for private creditors (specialised hedge funds) to profit. They purchase distressed debt well below par value, and by refusing to participate in the renegotiation process, attempt to recover the full face value of the debt. It is by virtue of enforcing the (original) terms of the loan and 'holding out' that the importunate creditor is able to entrap the sovereign debtor and force a web of complex repayments. Holdouts therefore undermine the financial system by gutting creditor rights and imperilling the willingness of investors to lend money to developing countries: this creates a distinctive coordination problem (the 'collective action' dilemma). ${ }^{16}$

Historically, (the enforceability of) sovereign debt contracts were overlooked given the principle of absolute legal immunity which protected sovereign debtors from legal action without their consent. The breakdown of absolute sovereign immunity has contributed to a rise in protracted holdout litigation. This was evidenced in the landmark case of Republic of Argentina $v$ Weltover. ${ }^{17}$ Here, the US Supreme Court held that sovereign debtors may be sued by private players within the market if conducting 'commercial activity'. ${ }^{18}$ The Court made a critical distinction positing that when a foreign government acts as a private player —as opposed to a market regulator, the foreign sovereign's actions are deemed 'commercial' within the scope of the Foreign Sovereign Immunities Act 1976. ${ }^{19}$

The holdout successes flowing from the Brussels Court of Appeal in Elliott Associates ${ }^{20}$ and the District Court for the Southern District of New York (reaffirmed by the Second Circuit Court of Appeals) in NML Capital Ltd $v$ Republic of Argentina ${ }^{21}$ raised significant fears of a 'paralytic effect' 22 on the functioning of the sovereign debt market — with Elliott in the latter proving victorious in its 15-year legal crusade against Argentina. ${ }^{23}$ This has generated controversy over the interpretative basis of the pari passu clause and its application as a weapon to disrupt the orderly restructuring of sovereign debt.

\section{The Securitisation of Sovereign Debts}

\footnotetext{
${ }^{15}$ Buchheit, 'The Sovereign Debt Restructuring Process' (n 6).

${ }^{16}$ Robin Wigglesworth, 'Lee Buchheit: The Crisis Veteran on the Sovereign Debt Frontline' Financial Times (1 July 2019) <https:/ftalphaville.ft.com/2019/07/02/1562040034000/-My-companions-on-the-trip-who-hadindulged-in-breakfast-lost-everything-but-their-regrets-/> accessed 10 April 2020.

${ }^{17}$ Republic of Argentina $v$ Weltover, Inc, et al, 504 US 607 (1992).

18 ibid 614; See also US Code, Title 28, s1605(a)(2).

${ }^{19}$ Republic of Argentina $v$ Weltover (n 17) 614; See also US Code, Title 28, s1605(a)(2).

${ }^{20}$ Elliott Associates, LP, Court of Appeal of Brussels, 8th Chamber, 26 September 2000.

${ }^{21}$ NML Capital, Ltd $v$ The Republic of Argentina, 03 Civ. 8845, 23 February 2012.

${ }^{22}$ Sergio Galvis, 'Solving the Pari Passu Puzzle', (2017) 12(2) Capital Markets Law Journal 204, 214.

${ }^{23}$ Robin Wigglesworth and Elaine Moore, 'Sovereign Debt: Curing Defaults' Financial Times (7 June 2016) $<$ https://www.ft.com/content/90dc38fa-2412-11e6-aa98-db1e01fabc0c > accessed 10 April 2020.
} 
Mexico's default in 1982 put a stop to cross-border lending and foreign capital throughout Latin America. A series of steps were taken to prevent further economic collapse of borrowing countries, as well as lending banks. The Brady Plan (1989) was seen as the most radical response to the capital deficiencies emanating from 'The Lost Decade' in the 1980s. The programme called for the United States and multilateral lending agencies (such as the International Monetary Fund) to cooperate with commercial bank creditors in restructuring the debt of those developing countries that were pursuing structural adjustments and economic programs supported by these agencies. ${ }^{24}$ The aim (in theory) was simple: to make the foreign economies more creditworthy and attract more capital for growth. ${ }^{25}$ Banks were allowed to securitise sovereign loans by voluntarily swapping non-performing loans for tradable (liquid) debt instruments (with a longer maturity profile), known as Brady bonds. For example, in 1985, the value of new international syndicated loans amounted to only $\$ 19$ billion, contrasting $\$ 137.2$ billion in gross Eurobond issues. ${ }^{26}$ This catalysed a shift in creditor lending patterns, reformulating the medium of cross-border lending towards Brady bonds.

The securitisation of Brady bonds presented new collective action challenges and reformulated the previous debtor-creditor relationship. This is seen in two instances. The first relates to the bonds' underlying liquidity and how they are traded. Bondholders are completely amorphous and anonymous people: this creates an underlying communication problem. ${ }^{27}$ This anonymity meant that investors did not feel the need to invest collectively or as a group with a common purpose and resulted in the divergence of interests and goals. Second, the securitisation of bonds provided investors with the opportunity to trade bonds and profit from the liquid sovereign debt market. This was shown through the commercial attractiveness of high yield Brady bonds, and led to the inception of specialist vehicles in distressed assets (vulture funds). The ability of emerging markets to issue bonds to a number of diverse investors (as a product of the securitisation of Brady bonds) therefore created the economic conditions for the holdout problem to emerge.

The sovereign bonds contained unanimous consent clauses (UCCs) which in practice made debt rescheduling unfathomably messy. This was problematic because it required consent

\footnotetext{
${ }^{24}$ Sharon Y Lee and Michael E Venezia, 'A Primer on Brady Bonds' (9 March 2000) 3.

25 Rodrigo Olivares-Caminal and others, Debt Restructuring (2nd edn, OUP 2016) 639; Ethan Kapstein, Governing the Global Economy: International Finance and the State (Harvard University Press 1994) 104.

${ }^{26}$ AC Chester, 'The International Bond Market' (Bank of England Quarterly Bulletin, November 1991) $521,522$. $<$ https:/www.bankofengland.co.uk/-/media/boe/files/quarterly-bulletin/1991/the-international-bondmarket.pdf?la=en\&hash=9EE4B8A723D505D99AA1CADA236124F5333527F2> accessed 10 April 2020.

${ }^{27}$ Sönke Häseler, 'Individual versus Collective Creditor Rights in Sovereign Bond Restructurings: An Economic Analysis' (Ph.D. Thesis, Institute of Law and Economics, University of Hamburg, 2012) 15-16 $<$ https://pdfs.semanticscholar.org/42f1/595e41ea248b18a1a9f791aadef772e8c2ca.pdf > accessed 10 April 2020.
} 
from all bondholders before any amendment could be made to the terms of the bonds (such as the maturity date). In other words, even if the bondholders decree that it is in their 'best interests' to restructure as soon as possible, the individual creditor may hold out, creating massive bargaining power vis-à-vis his/her fellow investors. ${ }^{28}$ Full payment to these holdout creditors would reduce the sovereign's available resources, further increasing incentives to hold out. ${ }^{29}$ This provided an avenue for minority creditors to severely disrupt the orderly restructuring of sovereign debt.

\section{Proposed Solutions}

In the early 2000s, market participants began developing legislative frameworks concerning responsible sovereign lending and borrowing, with an aim of changing how this important area of international finance functions in practice. ${ }^{30}$

One solution supported by senior policymakers was a treaty-based framework to restructure sovereign debt. This was publicly propounded by Anne Kruger in November 2001. ${ }^{31}$ The legal basis of the Sovereign Debt Restructuring Mechanism (SDRM) sought to create a formal Chapter 11-like bankruptcy forum that would preserve the country's asset values. Chapter $11^{32}$ of the United States Bankruptcy Code is a mechanism that allows a company to implement an operational and/or financial restructuring plan that is binding on dissenters. Through this proposal, the IMF hoped to promote a more orderly restructuring of sovereign debt. It aimed to counteract the holdout threat by allowing the sovereign debtor and majority creditors to use the law to bind holdouts to the terms of the restructuring agreement, thereby addressing the collective action problem and curbing creditor litigation. ${ }^{33}$ However, this was squarely rejected by the US and emerging market participants.

An alternative to the SDRM was to focus on the contractual provisions, namely through CACs. CACs evolved as result of the lessons learnt through recent debt crisis episodes to

\footnotetext{
${ }^{28}$ Sönke Häseler, 'Collective Action Clauses in International Sovereign Bond Contracts - Whence the Opposition?' (2009) 23(5) Journal of Economic Surveys 882, 883-84.

${ }^{29}$ Chanda DeLong and Nikita Aggarwal, 'Strengthening the contractual framework for Sovereign Debt Restructuring - The IMF's Perspective' (2016) 11(1) Capital Markets Law Journal 25, 26; Häseler, 'Individual versus Collective Creditor Rights in Sovereign Bond Restructurings: An Economic Analysis' (n 27) 15-16.

${ }^{30}$ Lee Buchheit and Mitu Gulati, 'Responsible Sovereign Lending and Borrowing' (2010) 73 Law and Contemporary Problems 63, 66.

${ }^{31}$ Sean Hagan, 'Designing a Legal Framework to Restructure Sovereign Debt', (2005) 36(2) Georgetown Journal of International Law 299, 302; Anne O Krueger, 'A New Approach to Sovereign Debt Restructuring' (IMF, Washington DC, April 2002), 2.

${ }^{32}$ United States Bankruptcy Code, Ch 11, Title 11,

${ }^{33}$ Krueger (n 31) 12-13.
} 
address the issues of coordination and preventing disruptive holdout positions. ${ }^{34} \mathrm{CACs}$ are seen as debtor-friendly tools that allows a supermajority of bondholders to bind the minority to the terms of the restructuring. The market-based approach and inclusion of CACs into the sovereign bonds was seen as a way to improve the debt restructuring process. This became the norm from mid-2003 onwards and by 2013 it had become standard market practice for international sovereign bonds. ${ }^{35}$ However, the holdout problem still remained as it was relatively easy for recalcitrant creditors to acquire a position large enough to block a restructuring for a given series of bonds. ${ }^{36}$

The importance of including CACs in sovereign bonds has been shaped by experiences such as that of Argentina - with a history of default and restructuring. ${ }^{37}$ It allowed recalcitrant creditors to use the pari passu clause to seek an injunction that prohibited Argentina from repaying the restructured bondholders until the holdouts were paid in full. The US Court of Appeals for the Second Circuit affirmed the injunction issued by the District Court. ${ }^{38}$ This required the sovereign debtor to pay those creditors that declined to participate in a debt reorganisation rateably with any payment made, thereby condemning Argentina for breaching its equal treatment obligation under the bond terms. ${ }^{39}$ It is important to note that there were no CACs in the sovereign bond documentation; this would have enabled Argentina to overcome the holdout problem. Judge Griesa's ruling in the South District New York Court therefore caused great concern to participants in sovereign bond markets and formed the basis for the recommendation and implementation of a more robust contractual framework for sovereign bonds. ${ }^{40}$

The body of this paper, having explored the contextual backdrop and holdout behaviour - the latter provoked by the securitisation of Brady bonds and the inefficient nature of unanimous consent clauses, will now evaluate the market-based solutions available to the sovereign debtor and provide judgment as to whether they meaningfully curtail the holdout problem.

\footnotetext{
${ }^{34}$ Olivares-Caminal, Debt Restructuring (n 25) 123.

${ }^{35}$ DeLong (n 29) 26.

${ }^{36}$ Andrea E Kropp, Mark C Weidemaier and Mitu Gulati, 'Sovereign Bond Contracts: Flaws in the Public Data?' (2018) 4(2) Journal of Financial Regulation 190, 203.

${ }^{37}$ Mark C Weidemaier and Mitu Gulati, 'A People's History of Collective Action Clauses' (2014) 54(1) Virginia Journal of International Law 1, 51-95 and especially 83; Antonia E Stolper and Sean Dougherty, 'Collective Action Clauses: How the Argentina Litigation Changed the Sovereign Debt Markets' (2017) 12(2) Capital Markets Law Journal 239, 243.

${ }^{38}$ NML Capital, Ltd v The Republic of Argentina, 699 F 3d 246, 255 (2d Cir 2012). See also Zandstra (n 10) 188.

${ }^{39}$ Lee C Buchheit and G Mitu Gulati, 'Restructuring Sovereign Debt after NML v Argentina' (2017) 12(2) Capital Markets Law Journal 224.

${ }^{40}$ Galvis (n 22) 204.
} 


\section{THE PARI PASSU CLAUSE - A SUBSTANTIVE ANALYSIS}

One of the most heated debates surrounding the law of debt restructuring concerns the shifting atextual interpretation of the pari passu clause ('by equal step' ${ }^{41}$ ). The purpose of this Section is to diagnose the legal aspects of debt reimbursement vis-à-vis recalcitrant creditors. This includes an evaluation of the extent to which litigation (Elliott Associates ${ }^{42}$ and $N M L^{43}$ ) has equipped holdouts with a new judicial remedy, and how this is counterbalanced by both White Hawthorn $^{44}$ and the revised pari passu clause. It will also explore the controversial 'rateable' interpretation of the pari passu clause. It argues that the reformed pari passu clause, by virtue of abating an obligation to effect rateable payments, goes a long way in mitigating the holdout threat.

In a corporate restructuring, most jurisdictions provide for an orderly restructuring of debt obligations and ranking system of priorities once a company has entered liquidation. The pari passu principle is a fundamental legal rule in corporate insolvency. It enables the unsecured creditors to equally share the proceeds of the putatively insolvent company that are available for residual distribution. As Street CJ put with characteristic lucidity in Kinsela $v$ Russell Kinsela $\mathrm{Ltd}^{45}$ : 'Where a company is insolvent the interests of the creditors intrude. They become prospectively entitled, through liquidation, to displace the power of the shareholders and directors to deal with the company's assets. ${ }^{46}$

However, in a sovereign debt restructuring, the pari passu principle is a contractual clause found in cross-border debt instruments. The purpose of the clause in this context is to maintain parity of treatment among creditors insofar as providing a warranty that on a liquidation or a forced distribution of assets by reason of insolvency, unsecured creditors will be entitled to a pro rata payment. ${ }^{47}$ The lack of international bankruptcy law covering the insolvency of sovereign states makes it difficult to agree a debt restructuring, given that debt relief can only be obtained with the creditors' consent. ${ }^{48}$ This disrupts inter-creditor equity insofar as the debt issued by a distressed sovereign is partly at the expense of existing creditors

\footnotetext{
${ }^{41}$ Black's Law Dictionary (9th edn, West 2009) 1225.

42 Elliott Associates (n 20).

${ }^{43}$ NML Capital (n 38).

${ }^{44}$ White Hawthorne, LLC v Republic of Argentina, 16-cv-1042 (TPG) (SDNY, 22 December 2016).

45 (in liq) (1986) 4 NSWLR 722.

46 ibid [730]. See also the Insolvency Act 1986, s143(1).

${ }^{47}$ Financial Markets Law Committee, 'Analysis of the Role, Use and Meaning of Pari Passu Clauses in Sovereign Debt Obligations as a Matter of English Law’ (March 2005) Issue 79 - Pari Passu Clauses Working Group 7.

${ }^{48}$ Buchheit, 'The Sovereign Debt Restructuring Process' (n 6) 3.
} 
who face a greater risk of default and will have to accept a greater haircut in the event of default. $^{49}$

\section{Elliott Associates}

Elliott Associates ${ }^{50}$ is fundamental to our understanding of the development of the holdout problem. ${ }^{51}$ This ruling was controversial in that it unleashed the 'rateable' payment interpretation and provided holdouts with an additional legal basis to enforce their contractual (pari passu) rights. ${ }^{52}$

The facts are as follows: the decrease in export prices of mining products and the 19821983 El Niño disaster locked Peru into a state of perpetual default from 1984-1997. In October 1995, Peru and the Bank Advisory Committee of Peru (BAC) announced an agreement in principle for a restructuring plan that covered most of the external commercial debt owed by Peru. Elliott Associates acquired \$20.7 million face value of defaulted Peruvian sovereign debt at a discounted price of $\$ 11.4$ million, believing the debt to be undervalued. ${ }^{53}$ It did not participate when Peru attempted to restructure its debt under the Brady plan and brought an action to enforce the debt in the Southern District of New York. ${ }^{54}$

In the United States Southern District Court of New York, Elliott sought money judgments based upon allegations of Banco's default under certain written loan agreements and Peru's default under a written guaranty securing certain loan agreements. ${ }^{55}$ Elliott submitted that Banco (the borrower) failed to meet its obligations under letters of credit assigned to Elliott to repay $\$ 7,000,000.00$ in principal and that Peru has failed to meet its absolute and unconditional guaranty of repayment of $\$ 20,682,699.04$ in principal. ${ }^{56}$ The defendants submitted that Elliott had purchased the debts contrary to New York Champerty laws (as the Peruvian loans were allegedly purchased for the purpose of bringing suit ${ }^{57}$ ), and that Elliott was not a proper assignee of the debt. They noted that the requisite 'Champertous' intent could be inferred through Elliott purchasing the debt with knowledge that Peru would not settle debt

\footnotetext{
${ }^{49}$ Patrick Bolton and David A Skeel Jr, 'Redesigning the International Lender of Last Resort' (2005) 6(1) Chicago Journal of International Law 177, 187.

${ }^{50}$ Elliott Associates (n 20).

${ }^{51}$ Mitu Gulati and Robert E Scott, The Three and a Half Minute Transaction: Boilerplate and the Limits of Contract Design (University of Chicago Press 2012) 12.

${ }^{52}$ Lee Buchheit and Jeremiah Pam, 'The Pari Passu Clause in Sovereign Debt Instruments' (2004) 53 Emory Law Journal 869, 879.

53 Cynthia Mullock, 'Sovereign Debt Restructuring Proposals and Their Effects on Emerging Markets Debt Investment' (2003) Chazen Web Journal of International Business (2003) 7.

54 ibid.

${ }^{55}$ Elliott Associates, LP v Republic of Peru, 12 F Supp 2d 328, (SDNY, 6 August 1998) [10] (Sweet J).

56 ibid, [16]-[18].

${ }^{57}$ New York Judiciary Law 1978, s489.
} 
agreements outside Brady perimeters, Elliott knowing Peru was in default when it made the purchases, and Elliott's prior involvement in litigation with the Republic of Panama. They also submitted that the court should deny attachment due to the risk it would pose to the Peruvian economy and people.

a) Enforcement: Champerty law

The New York District Court dismissed Elliott's complaint (and denied the writs of attachment) on the ground that Elliott's purchase of the Peruvian debt contravened New York Judiciary Law (the 'NY Law'). ${ }^{58}$ It held that was that at no point did Elliott demonstrate a good faith negotiating position; Elliot simply purchased Peruvian debt with the sole intention and purpose of suing outright; ${ }^{59}$ what was critical was that it had not even considered alternatives such as holding and reselling the debt, participating in Peru's privatisation program and the Brady Plan, or negotiating separately with the debtors to obtain terms more favourable than the Brady terms. ${ }^{60}$

\section{b) On Appeal: The Court of Appeals of the Second Circuit}

Conversely, the Court of Appeals of the Second Circuit, undercut the New York District Court's ${ }^{61}$ ratio on appeal with a more nuanced interpretation. It made a crucial distinction through the examination of the seminal Moses $v$ McDivitt. ${ }^{62}$ The Court stated that whilst an intention to sue on a claim promised does not offend the NY Law, to constitute an offense the primary purpose of the purchase must be to enable the creditor to bring a suit. In other words, the intent to bring a suit must therefore not be merely incidental and contingent. ${ }^{63}$ The Second Circuit Court held that Elliott did not violate the NY Law given its motivation to bring a suit against Nacion and Peru was subordinate to its intention to be paid in full for the purchased debt. ${ }^{64}$ Elliott was therefore awarded a judgment of $\$ 55$ million against Peru. ${ }^{65}$

c) Post-Judgment Reaction: Brussels Court of Appeal

In the aftermath of the judgment, Elliott moved to block the payment on the bonds in the Euroclear settlement system. The Brussels Court was asked (ex-parte) whether to grant Elliott an injunction to prevent Peru from making cash payments to holders of the Brady bonds unless

\footnotetext{
${ }^{58}$ Elliott Associates, LP v Republic of Peru (n 55).

59 ibid [332], [356].

60 ibid [342].

${ }^{61}$ Elliott Associates, LP v Banco de la Nacion and the Republic of Peru, 194 F 3d 363 (2nd Cir 1999).

6288 NY 62, 1882 WL 12577 (1882).

63 ibid [65].

${ }^{64}$ Elliott Associates, LP v Banco de la Nacion and the Republic of Peru (n 61) [379].

65 ibid.
} 
a proportionate payment was made to Elliott based on the pari passu provision contained in the original syndicated-loan contracts. ${ }^{66}$ Elliott relied upon Professor Lowenfeld's affidavit, which provided for a plain language ${ }^{67}$ reading of the pari passu clause. This broad or 'payment' interpretation was meant to include situations where the debtor is unable to pay its debt in full, and the creditors will be paid on a pro rata basis. This broader 'payment' interpretation had the effect of disarming the sovereign debtor from making preferential payments to one creditor over another when in default. Elliott was therefore able to persuade the Belgian courts to give it a pro rata priority of payment status with respect to all other external indebtedness of the Brady bondholders. ${ }^{68}$ This led to a full and final settlement of $\$ 58.45$ million, ${ }^{69}$ with Elliott obtaining some four hundred percent of the purchase value of Peru's defaulted bonds. ${ }^{70}$

The significance of the case cannot be understated: this was the first time the court issued an interpretation of the pari passu clause in at least a half-century. More significantly, it allowed Elliott to enforce its contractual claims through the rateable pari passu meaning. The breakdown in formal meaning of the pari passu clause which evolved to contain a second sentence referring to 'equal ranking of payment obligations' among the debtor's unsubordinated debts, contributed to the development of a debt restructuring regime that lacked coordination and inter-creditor safeguards. ${ }^{71}$

Whilst academics agree on the significance of the case, they disagree as to the immediacy of the threat of the pari passu clause. It is argued that the Brussels interpretation, contrary to academic opinion, moulded the pari passu clause into a legitimate ground for jeopardising Brady Bond payments: the Brussels Court conducted an act of veiled weaponisation. ${ }^{72}$ Notwithstanding the G-10's ${ }^{73}$ statement cautioning the rateable payment interpretation, market participants seemingly glossed over the implications of the Elliott Associates $^{74}$ litigation. Academics note the lack of academic commentary that addressed the rateable payment interpretation of the pari passu clause flowing from the Belgian Court's

\footnotetext{
${ }^{66}$ Elliott Associates (n 20). See also Manuel Monteagudo, 'Peru's Experience in Sovereign Debt Management and Litigation: Some Lessons for the Legal Approach to Sovereign Indebtedness' (2010) 73(4) Law and Contemporary Problems 201, 208.

${ }^{67}$ Elliott Associates (n 20) [11]-[12] (Declaration of Professor Andreas Lowenfeld).

68 ibid.

69 ibid; Supreme Decree No 106-2000-EF. See also Rodrigo Olivares-Caminal, 'Understanding the Pari Passu Clause in Sovereign Debt Instruments: A Complex Quest' (2009) 43(3) The International Lawyer 1217, 1225.

${ }^{70}$ Olivares-Caminal, 'Understanding the Pari Passu Clause in Sovereign Debt Instruments: A Complex Quest' (n 69) 1225.

${ }^{71}$ Bank for International Settlements, 'Sovereign Risk: A World Without Risk-free Assets?' (July 2013) 72 BIS Papers 97.

${ }^{72}$ Buchheit, ‘The Pari Passu Clause in Sovereign Debt Instruments' (n 52) 878-79.

${ }^{73}$ Group of Ten, 'Report of the G-10 Working Group on Contractual Clauses' (26 September 2002).

${ }^{74}$ Elliott Associates (n 20).
} 
decision. ${ }^{75}$ Perhaps market participants were blinded by the barrage, albeit fruitless, of pari passu litigation that ensued; ${ }^{76}$ Such key players seemed to be caught off guard (knowingly or unknowingly) by this looming pari passu quandary: the IMF was unmindful as to the issue of debt dilution and lack of enforcement of seniority in sovereign debt. To comment that "no harm ultimately arose ${ }^{77}$ from this crucial decision is therefore an understatement. Cheering at the denouement of the restrictive interpretation provided by the English Court of Appeal ${ }^{78}$ and the legislation ${ }^{79}$ used to quash the injunction ${ }^{80}$ issued by the District Court for the Central District of California in Red Mountain ${ }^{81}$ (where the court ruled that pari passu did not entitle creditors to specific performance), market participants neglected the implications of Elliott Associates. ${ }^{82}$ Surely it was a matter of time before a case unveiled (as opposed to create) ${ }^{83}$ the pari passu weapon.

\section{The Pari Passu Controversy: Does NML v Argentina Hold Its Worth?}

Given the Belgian Court's questionable judicial decision on the pari passu clause in Elliott Associates, ${ }^{84}$ the Argentina litigation led to further uncertainty in the market regarding the rateable payment interpretation and more generally the impact holdouts could exercise in sovereign debt restructurings going forward. ${ }^{85}$

Argentina defaulted on $\$ 80 \mathrm{bn}$ of its bonds issued pursuant to its Fiscal Agency Agreement (FAA) and offered new bonds to its bondholders in 2005 and $2010 .{ }^{86}$ It succeeded in restructuring $93 \%$ of its external debt through the 2005/2010 exchange offers and withheld payments to the holdout creditors who did not tender the bonds in default. ${ }^{87}$ To encourage

\footnotetext{
${ }^{75}$ Buchheit, 'The Pari Passu Clause in Sovereign Debt Instruments' (n 52) 879.

${ }^{76}$ Red Mountain Finance, Inc v Democratic Republic of Congo and National Bank of Congo, Case No CV 000164 R (CD Cal, 29 May 2001); Kensington International Ltd v Republic of the Congo [2003] EWCA Civ 709; Nacional Financiera, SNO v Chase Manhattan Bank, NA, No 00 Civ 1571 (JSM), 2003 WL 1878415, (SDNY, 14 April 2003) [2].

77 David Newfield, 'Pari Passu as a Weapon and the Changes to Sovereign Debt Boilerplate after Argentina v NML' (2016) 24(3) University of Miami Business Law Review 175, 180.

${ }^{78}$ Kensington International (n 76).

${ }^{79}$ Red Mountain Finance Inc v Democratic Republic of Congo, Stipulation and Order No 2:00-CV-00164-MLR (CD Cal, 10 June 2002), ECF No 238.

${ }^{80}$ Red Mountain Finance Inc v Democratic Republic of Congo, Injunction Order No CV 00-0164 R (BQRx) (CD Cal, 29 May 2001), ECF No 123.

81 ibid.

${ }^{82}$ Elliott Associates (n 20).

${ }^{83}$ Buchheit, 'Restructuring Sovereign Debt after NML v Argentina' (n 39).

${ }^{84}$ Elliott Associates (n 20).

${ }^{85}$ Galvis (n 22) 204.

${ }^{86}$ ibid 206.

87 ibid; International Monetary Fund, 'Strengthening the Contractual Framework to Address Collective Action Problems in Sovereign Debt Restructuring’ (Washington DC, October 2014) Policy Paper 8-9.
} 
creditor participation in the exchange offer, it promulgated the 'Lock Law' ${ }^{\text {'8 }}$ on $19^{\text {th }}$ February 2005. ${ }^{89}$ This created a hierarchy of bondholders and had the effect of prohibiting the reopening of the swap process and, barring any type of in-court, out-of-court, or private settlement with non-participating (lower ranking) bondholders. ${ }^{90}$ In 2011, NML Capital sued for the repayment of principal and past-due interest claims, asserting that the Republic had breached the pari passu clause in its 1994 FAA and sought specific performance. ${ }^{91}$

Judge Griesa in the South District New York Court ${ }^{92}$ granted an injunction based upon the breach of the pari passu clause. ${ }^{93} \mathrm{He}$ focused on four elements: the enactment of the 'Lock Law'; Argentina's 2001 moratorium; the disparity between payments on unrestructured bonds and those pertaining to the debt restructuring programme; and Argentina's prospectus which stated that it had no intention of paying the non-tendered bonds. ${ }^{94} \mathrm{He}$ took these elements as forming the basis for Argentina's discriminatory actions as a uniquely recalcitrant debtor and fashioned a powerful injunctive remedy, which effectively closed off any viable method for Argentina to pay the Exchange Bonds without also paying the holdouts. ${ }^{95}$

The Second Circuit Court of Appeal ${ }^{96}$ unanimously affirmed the orders of the District Court and applied basic principles of contractual interpretation to demystify the semantic uncertainty surrounding the pari passu clause. ${ }^{97}$ Importantly, the Court did not comment upon whether the enactment of a legislative measure, standing alone, could breach the pari passu provision. ${ }^{98}$ It simply reasserted Judge Griesa's dictum in stating that the equal treatment provision prohibited Argentina from 'paying on other bonds without paying on the FAA bonds', and that Argentina breached the pari passu clause by making payments on the exchange bonds but not the FAA bonds. ${ }^{99}$

\footnotetext{
${ }^{88}$ Ley 26.017 (2005) Disposiciones adicionales a las que quedarán sujetos los bonos del Estado Nacional que resultan elegibles para el canje establecido en el Decreto $\mathrm{N}^{\circ}$ 1735/2004 y que no hubiesen sido presentados al canje dispuesto por el mencionado decreto. Ratifícase el Decreto $N^{\circ}$ 733/2004 (ley cerrojo).

${ }^{89}$ Galvis (n 22) 206.

${ }^{90}$ Robert Cohen, “'Sometimes a Cigar is Just a Cigar": The Simple Story of Pari Passu' (2011) 40(1) Hofstra Law Review 11, 20.

${ }^{91}$ Galvis (n 22) 206.

${ }^{92}$ NML Capital (n 38).

${ }^{93}$ NML Capital, Ltd v The Republic of Argentina, Order No 08 Civ 6978 (TPG) (SDNY, 7 December 2011) [2].

${ }^{94}$ NML Capital (n 38) 250-252, 260, 264. See also Buchheit, 'Restructuring Sovereign Debt after NML v Argentina' (n 39) 226.

${ }^{95}$ NML Capital (n 38) 207.

${ }^{96}$ ibid 260, 264.

${ }^{97}$ ibid 242.

${ }^{98}$ Buchheit, 'Restructuring Sovereign Debt after NML v Argentina' (n 39) 226.

99 ibid; Howard Steel, Elnaz Zarrini and Arkady Goldinstein, 'NML Capital v Argentina: A Lesson in Indenture Interpretation' (2014) 8(2) Insolvency and Restructuring International 31, 32.
} 
It is argued that the $N M L^{100}$ litigation is wrong as a matter of contractual interpretation. ${ }^{101}$ This is because Judge Griesa was able to formally unveil the pari passu weapon, which had the effect of providing holdouts with greater protection from subordination. More pertinently, the case advanced the little-accepted interpretation of the rateable meaning. ${ }^{102}$ Such interpretation effectively gave recalcitrant creditors the power to control a country's ability to repay its debts, by preventing the country from repaying its renegotiated bondholders until the holdout creditors' debts were satisfied. ${ }^{103}$ This exacerbated the collective action problem inherent in sovereign bonds; by increasing the negotiating leverage of holdout creditors who would have solid expectations of obtaining preferential settlements, it made it harder for sovereigns to generate adequate incentives for their bondholders to participate in future exchanges in other restructuring contexts. ${ }^{104}$ Moreover, the nature of the remedy was controversial; instead of providing a contractual remedy (acceleration) and a monetary award for the breach, the court prevented Argentina from making payments on its restructured bonds unless holdouts were paid in full. ${ }^{105}$ This had the effect of allowing vulture funds to launch 'a terrorism of payments and settlement systems'. ${ }^{106}$

Gulati, Buchheit and $\operatorname{Scott}^{107}$ concur, launching a heavy critique on the pari passu clause. They submit that sophisticated parties, rather than tailoring standardised contracts to precisely articulate their needs, copy the standard forms, making minor modifications at the margins to meet their clients' objectives. ${ }^{108}$ This results in a contractual black hole (where clauses are rendered 'largely meaningless' and full of random variations). ${ }^{109}$ This justifies their view that the term did not mean what the South District New York Court said that it meant. ${ }^{110}$ In addition, they contend that the 'rateable interpretation' strengthens the hands of rogue holdout creditors, allowing them to go beyond the sovereign debtor and attack other creditors who might have received payments from the sovereign. ${ }^{111}$ This undermines any efforts to

\footnotetext{
${ }^{100}$ NML Capital (n 38).

${ }^{101}$ Buchheit, 'Restructuring Sovereign Debt after NML v Argentina' (n 39) 226.

102 DeLong (n 29) 4.

${ }^{103}$ Newfield (n 77) 179.

${ }^{104}$ International Monetary Fund (n 87) 11; Galvis (n 22) 207.

105 DeLong (n 29) 5.

${ }^{106}$ Robin Wigglesworth and Jude Webber, 'Markets: An Unforgiven Debt' Financial Times (27 November 2012) $<$ https://www.ft.com/content/11558dc6-3888-11e2-bd7d-00144feabdc0> accessed 1 April 2020.

${ }^{107}$ Stephen J Choi, Mitu Gulati, and Robert E Scott, 'Evolution or Intelligent Design? The Variation in Pari Passu Clauses' (9 October 2016) 2.

108 ibid 32.

109 ibid 33-34.

110 ibid 2.

111 ibid 12.
} 
restructure sovereign debt in the future. ${ }^{112}$ Keeping the provision in sovereign bond documentation therefore plays into the hands of those "whose sole interest is to maximize their profit at the expense of others and who will create the maximum of disruption to achieve their ends'. 113

However, Cohen sides with Judge Griesa's interpretation, advocating for the plain reading of the pari passu clause. ${ }^{114}$ He notes that the simple promise of equality, understood by the original investors in the sovereign debt, is understood by today's investors and is recognised by the courts that have been asked to enforce pari passu's plain language. ${ }^{115}$ Furthermore, he contends that the plain-meaning interpretation of pari passu provisions conforms with common sense and business realities, ${ }^{116}$ given the lack of judicially supervised insolvency proceedings for sovereigns, the pari passu clause, provides protection to creditors and serves as a mechanism allowing for the functional subordination of sovereign debt. ${ }^{117}$

Cohen's pro-creditor position cannot simply use the lack of a bankruptcy regime as a pretext for granting holdouts a weapon to disrupt future sovereign debt restructurings and encourage holdout creditors to litigate for full payment. ${ }^{118}$ Instead, this paper argues along different lines: the pari passu quandary in $N M L^{119}$ is further eroded by White Hawthorne. ${ }^{120}$ Here, the District Court deployed an important limiting principle to its interpretation of the pari passu clause, in finding that payment to some creditors but not others does not on its own violate the pari passu clause. ${ }^{121}$ If litigated today, Argentina would not be guilty of breaching the pari passu clause by paying some creditors and not others. ${ }^{122}$ Judge Griesa's opinion further noted that "non-payment of defaulted debt alone is insufficient to show breach of a pari passu clause'. ${ }^{123}$ This confines the application of injunctions to extraordinary circumstances - for example where there is a combination of executive declarations and coercive legislative

\footnotetext{
${ }^{112}$ Rodrigo Olivares-Caminal, 'To Rank Pari Passu or Not to Rank: That Is the Question in Sovereign Bonds after the Latest Episode of the Argentine Saga' (2009) 15(4) Law and Business Review of the Americas 745, 746; Mitu Gulati, The Three and a Half Minute Transaction: Boilerplate and the Limits of Contract Design (n 51) 15.

${ }^{113}$ Lachlan Burn, 'Pari Passu Clauses: English Law After NML v Argentina' (2014) 9(1) Capital Markets Law Journal 2, 9.

${ }^{114}$ Cohen (n 90).

115 ibid 14.

116 ibid 17.

117 ibid.

${ }^{118}$ Ahmed (n 11) 141.

${ }^{119}$ NML Capital (n 38).

${ }^{120}$ White Hawthorne (n 44).

${ }^{121}$ Blakemore (n 9).

122 ibid.

${ }^{123}$ White Hawthorne, LLC v Republic of Argentina, 16-cv-1042 (TPG) (SDNY, 22 December 2016), Opinion 3.
} 
enactments (such as Lock Law) of a uniquely recalcitrant debtor. ${ }^{124}$ Such modified reading of the pari passu clause -where a breach per se does not give rise to a claim for money damages serves to mitigate much of the harshness of the Argentina litigation, and delimits the long-term significance of the Brussels Court's interpretation and Second Circuit's reaffirmation. ${ }^{125}$ This decision emphasises that an equal treatment clause is violated in only the rarest of cases and constricts $N M L$ 's rateable interpretation. ${ }^{126}$

However, it is argued that the revised pari passu clause mitigates much of the harshness of the rateable interpretation espoused in $N M L$, notwithstanding White Hawthorn. ${ }^{127}$ The ICMA's ${ }^{128}$ revised pari passu clause addresses the equal payment dilemma by reducing the probability of an outcome where a judge rules that participating bondholders cannot be paid unless holdout investors also are paid. ${ }^{129}$ It states that:

[T] he Issuer shall have no obligation to effect equal or rateable payment(s) at any time with respect to any such other External Indebtedness and, in particular, shall have no obligation to pay other External Indebtedness at the same time or as a condition of paying sums due on the Notes and vice versa. ${ }^{130}$

This has been favourably viewed by market participants and has triggered sovereign issuers such as Colombia ${ }^{131}$ and Panama ${ }^{132}$ to modify the standard pari passu clause in their prospectus to explicitly exclude such interpretation. Such harmonisation of the pari passu clause enhances legal certainty and consistency across jurisdictions — as well as facilitates more predictable outcomes for debtors and creditors, and fairer outcomes among creditors. ${ }^{133}$

Overall, there is no doubt that debt securitisation created the necessary conditions to enable holdouts to thrive: Elliott Associates ${ }^{134}$ and $N M L^{135}$ have given holdouts greater

\footnotetext{
${ }^{124}$ Sulivan \& Cromwell LLP, 'Sovereign Debt Litigation: District Court Opinion Limits the Applicability of Previous Pari Passu Decisions in the Argentine Debt Litigation' (29 December 2016).

${ }^{125}$ Galvis (n 22) 211.

${ }^{126}$ Blakemore (n 9),

${ }^{127}$ NML Capital (n 38); White Hawthorne (n 44).

${ }^{128}$ ICMA, 'Standard Pari Passu Provision for the Terms and Conditions of Sovereign Notes' (August 2014).

${ }^{129}$ Gregory Makoff and Robert Kahn, 'Sovereign Bond Contract Reform: Implementing the New ICMA Pari Passu and Collective Action Clauses' (February 2015) 56 CIGI Papers 5.

${ }^{130}$ ICMA (n 128).

${ }^{131}$ SEC, 'Final Prospectus Supplement: Republic of Colombia' (16 March 2016) Filed Pursuant to Rule 424(b)(5) Registration No 333-202025.

${ }^{132}$ SEC, 'Final Prospectus Supplement: Republic of Panama' (17 July 2019) Filed Pursuant to 424(b)(5) File No $333-223218$.

${ }^{133}$ Makoff (n 129) 1; DeLong (n 29) 5.

${ }^{134}$ Elliott Associates (n 20).

${ }^{135}$ NML Capital (n 38).
} 
leverage, potentially dampening the restructuring process. ${ }^{136}$ Nevertheless, it is argued that the early Brussels decisions may be viewed as more complex than the critics let on, flying in the face of the prevailing understanding of the pari passu clause in sovereign debt and the market practices that had developed around it. ${ }^{137}$ Whilst Cohen's loose constructionist interpretation of the pari passu clause is persuasive, there is less risk that English courts, faced with similar facts to $N M L,{ }^{138}$ would adopt the 'payment' interpretation; White Hawthorne ${ }^{139}$ has dealt a serious blow to creditors who would seek to follow in the hedge funds' footsteps and rouse a dormant equal treatment provision to stymie a sovereign's restructuring efforts in hopes of a windfall. ${ }^{140}$ It is correct to say that that the Elliott Associates ${ }^{141}$ and $N M L^{142}$ decisions are problematic: the pari passu clause does not require actual uniformity of treatment and should be understood to be interpreted narrowly. Overall, the revised pari passu clause succeeds in curtailing the rateable payment threat so as to discourage excessive litigation posed by recalcitrant creditors.

\section{THE COLLECTIVE ACTION DILEMMA}

Having established the dilemmas caused by the application of the pari passu clause in fuelling holdout behaviour, this paper will now discuss the debtors' response to the holdout problem in a specific European context, and then move onto an analysis about the particular features of the revised CACs - and its efficacy in mitigating recalcitrant leverage.

The international system lacks an effective legal framework for the predictable and orderly restructuring of sovereign debt: this is conducive to holdout behaviour and litigation. CACs are presented as one answer to the holdout problem and have evolved as result of the lessons learnt through recent debt crisis episodes in order to prevent disruptive holdout positions. ${ }^{143}$ This is done through two types of provisions: first, majority restructuring provisions allow the debtor and (the majority of) creditors to reach an agreement binding upon all bondholders including recalcitrant (minority) creditors; ${ }^{144}$ and second, majority

\footnotetext{
136 Tapas Strickland, 'Sovereign Debt Restructuring: Recent Issues and Reforms' (2014) RBA Bulletin 73, 74.

${ }^{137}$ Anna Gelpern, 'Building a Better Seating Chart for Sovereign Restructurings' (2004) 53(3) Emory Law Journal $1115,1138$.

${ }^{138}$ NML Capital (n 38).

${ }^{139}$ White Hawthorne (n 44).

140 Blakemore (n 9).

${ }^{141}$ Elliott Associates (n 20).

${ }^{142}$ NML Capital (n 38).

${ }^{143}$ Olivares-Caminal, Debt Restructuring (n 25) 123.

${ }^{144}$ Matthias Herdegen, Principles of International Economic Law, (2nd edn, OUP 2016) 553.
} 
enforcement provisions bar recalcitrant creditors from enforcing claims through litigation. ${ }^{145}$ CACs therefore seek to provide a more orderly framework for restructuring debt by binding non-consenting recalcitrant creditors with the consent of a qualified majority of creditors. ${ }^{146}$

\section{Euro CACs}

A practical problem facing European countries such as Italy, is how best to restructure their debt obligations. Depending on the composition of their debt stock and its governing law, the debate here concerns whether European sovereigns can replicate the Greek example and use the local law advantage tool to facilitate an eventual restructuring of their bonds.

Emerging market sovereigns issue bonds governed by a foreign regime such as the law of New York. In the same accord, European sovereigns have been able to issue bonds governed by the issuer's own law. In the event of a crisis, the latter is able to pass legislation to have retrospective effect on the debt instrument and facilitate a restructuring of their bonds. This is what is termed the 'local law' advantage and is important in the discussion as it provides another tool sovereign debtors can use to mitigate the holdout problem.

To contextualise this discussion, the salient facts of the Greek restructuring are outlined. Greece attempted to restructure its sovereign bonds in 2012. $€ 177.3$ billion (over 90 percent of debt stock) was governed by local law. ${ }^{147}$ The central problem was distinctly legal: the issuance contained no CACs meaning that these bonds could only be restructured with the unanimous consent of all bondholders. ${ }^{148}$ Greece surmounted the 'impossible hurdle' by deploying legislation ${ }^{149}$ that removed the unanimity clause and retrofitted cross-series aggregation CACs into Greek bonds. This led to the acceptance of a healthy $82.5 \%$ of Greek-law bondholders in the exchange offer. ${ }^{150}$

It is argued that the local law advantage is a viable response to the holdout threat and should be enjoyed by most Euro-area sovereigns to facilitate an orderly restructuring of sovereign debt in Europe. ${ }^{151}$ The mildest use of Greece's local law advantage was chiefly

\footnotetext{
145 ibid.

${ }^{146}$ Francis B Palmer, Company Precedents (2nd edn, 1881) 271.

147 Jeromin Zettelmeyer, Christoph Trebesch and Mitu Gulati, 'The Greek Debt Restructuring: An Autopsy' (2013) 28(75) Economic Policy 513, 552.

148 ibid 4; Kirsten Erichsen and Andrew Wilkinson, 'Sovereign Debt Restructuring: What Can we Learn from Argentina, Greece and Ukraine?’ (2016) 7(419B) Butterworths Journal of International Banking and Financial Law 1.

${ }^{149}$ Greek Bondholder Act, Law 4050/2012, Official Government Gazette 36/A/23-2-2012.

${ }^{150}$ Zettelmeyer (n 147) 526.

${ }^{151}$ Lee C Buchheit and G Mitu Gulati, 'Use of the Local Law Advantage in the Restructuring of European Sovereign Bonds' (2018) 3(2) University of Bologna Law Review 172, 176.
} 
undertaken to ensure that the restructuring would not be undermined by a holdout minority. ${ }^{152}$ By addressing this central concern, Greece provided a solution to the longstanding problem cited by the G-10 of ensuring that there were effective means for creditors and debtors to recontract without a minority of debt-holders obstructing the process. ${ }^{153}$ Nevertheless, the use of legislative sovereignty must be cautioned given that it undermines the fundamental premise that contracts will be enforced as written. ${ }^{154}$ Thus, utilising the sovereign's unique ability to change the rules governing its own commitments is considered fundamental to the successful restructuring of debt — and an advantage over emerging market sovereigns whose bonds are governed by foreign law.

It logically follows that when confronted with a particularly malaise debt crisis in a European country, sovereigns should have the ability to follow the Greek example, and opt for the riskier tact of using their local-law debt to facilitate a debt restructuring: such technique should be seen as a tool not in lieu of Euro CACs but in addition to it. The presence of CACs in local law sovereign bonds should not prevent local legislatures from transplanting class voting mechanisms across the entire debt stock of sovereign bonds. ${ }^{155}$ This follows the spirit of Weidemaier who presents a pertinent case that the 'local law advantage' makes the restructuring of sovereign debt 'comparatively easy'. ${ }^{156}$ The texture of his analysis does not view CACs as a way of repudiating the local law advantage, but rather, as opening a new path to debt relief for a sovereign that can win the support of a bondholder majority: this would offer much needed flexibility and discretion to sovereigns. ${ }^{157}$ It is therefore argued that whilst CACs may shackle the local law advantage, it should by no means constrain its application absolutely. ${ }^{158}$

However, Galli contends that CACs are the only way to restructure a Euro area nation's sovereign debt. ${ }^{159} \mathrm{He}$ cites that the intention of the technical committee that drafted the CAC regulation was not to preserve the putative local law advantage, but rather to create a uniform

\footnotetext{
152 ibid; Yannis Manuelides, 'Using the Local Law Advantage in Today's Eurozone' (21 June 2019) 3 $<$ https://papers.ssrn.com/sol3/papers.cfm?abstract_id=3405422> accessed 11 April 2020.

${ }^{153}$ Group of Ten (n 73) 1.

${ }^{154}$ Buchheit, 'Use of the Local Law Advantage in the Restructuring of European Sovereign Bonds' (n 152) 176.

${ }^{155}$ Lee C Buchheit and G Mitu Gulati, 'Sovereign Debt Restructuring in Europe' 9(1) (2018) Global Policy 65, 68.

${ }^{156}$ Mark Weidemaier, 'Restructuring Italian (or Other Euro Area) Debt: Do Euro CACs Constrain or Expand the Options?' (2 April 2019) UNC Legal Studies Research Paper 1 $<$ https://papers.ssrn.com/sol3/papers.cfm?abstract_id=3364982> accessed 10 April 2020.

157 ibid 3.

158 ibid 4.

${ }^{159}$ Giampaolo Galli, 'Collective Action Clauses and Sovereign Debt Restructuring Frameworks: Why and When is Restructuring Appropriate' in Franklin Allen and others, European Financial Infrastructure in the Face of New Challenges (European University Institute 2019) 2.
} 
and predictable system for all future debt restructurings throughout Europe. ${ }^{160}$ This, he argues, is bolstered by Article $12^{161}$ which attempts to implement CACs 'in a way which ensures that their legal impact is identical'. ${ }^{162}$ Taking a purposive reading, it is fair to say that it was in the committee's intentions to harmonise CACs in the euro area. The rationale is that once the Euro CACs voting requirements are fulfilled, it will be able to comfortably prevent tyranny of the minority (i.e. the holdout formation). ${ }^{163}$ Galli's argument therefore premises upon a plain textual analysis of the ESM Treaty that principally endorses the use of CACs in restructuring sovereign debt and addressing the collective action problem. ${ }^{164}$

It is axiomatic that legislators and the judiciary have generally accepted (Euro) CACs as a centrepiece of the Eurozone's framework to address sovereign debt crises. ${ }^{165}$ Whilst the local law option is a risk given the implications of litigation that would detract from its appeal, in practice, Euro CACs are viewed as the most suitable and safe way of undergoing a debt restructuring. ${ }^{166}$ But, if Galli is correct, it would restrict the tools Eurozone sovereigns have at their disposal to deal with a loss of market access. ${ }^{167}$ Galli's argument is therefore seen as too restrictive; exclusively following the Euro CAC approach would deprive sovereigns of much needed freedom to use the local law advantage to facilitate debt restructurings and mitigate holdout leverage. Euro CACs should therefore be seen as one solution to resolve the puzzle of collective action by maximising utility both in the aggregate and per class of stakeholders whilst minimising overall losses. ${ }^{168}$ This paper prefers Weidemaier's argument that lends itself to ex ante contractual reform but preserves the legislative sovereignty option (applicable under narrowly defined emergency situations). ${ }^{169}$ Euro CACs are therefore not the only mechanism available to restructure debt and must be considered more broadly as part of a portfolio of tools available to Eurozone sovereigns. ${ }^{170}$

\section{Bondholder Voting: The Verdict}

\footnotetext{
160 ibid.

161 Treaty Establishing the European Stability Mechanism [2012] OJ L91/1 art 12 para 3.

162 ibid.

163 Palmer (n 146) 271.

164 Galli (n 159) 3.

${ }^{165}$ Steffen (n 7) 141.

166 Galli (n 159) 3.

167 Manuelides (n 152) 12.

168 ibid.

${ }^{169}$ Steffen (n 7) 141; Manuelides (n 152) 2.

170 Clifford Chance, 'Euro Area Member States Take Collective Action to Facilitate Sovereign Debt Restructuring' (December 2012) Collective Action Clauses for the Euro Area - Briefing Note.
} 
Having established another means by which the sovereign debtor is able to fend off holdout creditors by relying on their own legislatures to ultimately facilitate a future restructuring of debt instruments, this paper will now examine how the technical features underpinning CACs enables the debtor to mitigate holdout activism. Specifically, this Section addresses how aggregated CACs add value to new international sovereign bond issuances: it examines the bondholder voting mechanisms ${ }^{171}$ and then considers the extent to which the enhanced CACs provide for a more efficient restructuring of sovereign debt. To argue that the reformed CACs militate against holdout leverage by providing a wider relief menu and granting flexibility to the sovereign debtor is over-simplistic. Rather, this paper argues that (single-limb) CACs are the most potent form of restructuring for a sovereign who is seeking a comprehensive restructuring to restore its solvency after a payment default (where the holdout risk is largest). ${ }^{172}$

\section{Revised CACs - added value?}

The holdout risk triggered a need for contractual solutions to address the problem of nonconsenting creditors and protracted restructurings. The reformed CACs provide the sovereign debtor with a wider menu (of voting procedures), giving it multiple options to extract consent from bondholders. This includes: modification of a single series of notes; modification of multiple series of notes, with a requirement that the restructuring be approved both by all noteholders voting together and by noteholders voting within their particular notes (two-limb voting); and modification of a multiple series of notes, with one aggregated vote amongst all noteholders (single-limb voting). ${ }^{173}$

\section{a) Series-by-Series Voting Procedure}

The classic series-by-series CAC voting design prior to the 2015 reform was seen as a welcome change from the traditional unanimous action clauses (UACs). This resulted in holdouts remaining in every sovereign restructuring since the Brady bonds were first issued in the late 1980s. ${ }^{174}$ The market adopted these changes with Mexico adding the first series-by-series CACs in 2003.

A hypothetical example helpfully explains the essence of this procedure. The bondholders of Series A are as follows: AG Capital (as to 1/4), BC Management, NML Vulture

\footnotetext{
${ }^{171}$ ICMA, 'ICMA Sovereign Bond Consultation Paper' (December 2013) 4-9.

172 Anna Gelpern, Ben Heller and Brad Sester, 'Count the Limbs: Designing Robust Aggregation Clauses in Sovereign Bonds' in Martin Guzman, José Antonio Ocampo and Joseph E Stiglitz (eds), Too Little, Too Late: The Quest to Resolve Sovereign Debt Crises (Colombia University Press 2016) 124.

173 ICMA, 'Standard CACs Pari Passu and Creditor Engagement Provisions' (May 2015) 3-4. Zandstra (n 10) 193.

${ }^{174}$ Stolper (n 37) 243.
} 
and Elliott Corpn ${ }^{175}$ (with 3/4 of the outstanding principal). If the holders of $3 / 4$ of the bonds of Series A negotiate a deal with the sovereign, this would have a cram-down effect on AG Capital, forcing it to accede to the new restructuring terms. ${ }^{176}$

However, whilst series-by-series voting is viewed as a viable solution to addressing the holdout problem, such mechanism is not without limitations. This is because AG Capital can still obtain a formidable blocking position in Series A, preventing it from undergoing a successful restructuring. This is a justifiable concern for the sovereign debtors as it exacerbates the holdout problem and disrupts the restructuring process further. It also undermines intercreditor equity: AG Capital's influence (by obtaining a blocking position) will also affect the ability of the $3 / 4$ bondholders to agree a consensual restructuring. As such, series-by-series voting whilst underlining the value of majority action, is not per se the most effective way of mitigating intransigent holdouts. The Argentina crises demonstrates the severe limitations of this clause, with market participants opting for more refined aggregated CACs instead. This was shown through holdouts blocking payments on restructured bonds, upsetting the delicate balance between risk and reward that drove investor participation in earlier restructurings. ${ }^{177}$

\section{b) Aggregated CACs: Dual-Limb}

The dual-limb CACs make it easier to reach the threshold requirement necessary to impose a cramdown on obdurate holdouts. It allows all debt securities issued to be considered together in a restructuring if the debtor was unable to pay. ${ }^{178}$ Two-thirds in total principal amount of the series being aggregated and at least 50 percent of each voting series is required to amend the reserve matters. ${ }^{179}$ By diluting the threshold requirement for the minimum participation in each series from 75 percent to 66.66 percent, it makes it more difficult and costly for holdouts to pose a threat by virtue of obtaining a blocking position in Series A. ${ }^{180}$ This has an impact on inter-creditor equity (equality): when it is certain that Series A, B, C and D will be restructured, this is enough to encourage participation from holders knowing that others are bound by the restructuring. ${ }^{181}$

However, whilst it may be argued that aggregated CACs partly address the market dislocations through cross-series modification, it still does not fully eliminate the holdout

\footnotetext{
${ }^{175}$ Disclaimer: names for illustrative purposes only.

${ }^{176}$ Lee Buchheit, 'Sovereign Bonds and the Collective Will' (2002) 51(4) Emory Law Journal 1317, 1345.

177 Gelpern (n 172) 111.

${ }^{178}$ Zandstra (n 10) 186; Stolper (n 37) 240.

179 ibid.

${ }^{180}$ DeLong (n 29) 6.

181 ibid.
} 
problem. This is because investors could still hold or buy a blocking percentage of a particular series of bonds in order to ensure that they remain outside any restructuring agreed by other bondholders; holdouts could then seek to find ways to disrupt such a restructuring to increase their negotiating leverage or chances of a full recovery. ${ }^{182}$

c) Aggregated CACs: Single-Limb

It is argued that the use of single-limb CAC is considered more efficient since it permits an issuer to conduct separate votes for those groups. Pertinently, it allows the sovereign debtor to aggregate the votes of holdouts of all series of outstanding bonds, making it more difficult for a holdout to acquire a blocking position across Series A-D. ${ }^{183}$ The IMF openly acknowledges its positive effects, underpinning the merit that such a robust form of aggregation successfully introduces into international sovereign bonds. ${ }^{184}$ Moreover, to the extent that the issuer wishes to offer different terms to different bond series, aggregated CACs offer a wide relief menu of voting procedures to suit the sovereign debtor. ${ }^{185}$

One of the benefits of a corporate restructuring is that there is a court oversight over bankruptcy classification and voting. This enables creditor rights to be protected. For example, the court may act to prevent the interests of the holders of one series of bonds from being overridden by a majority of the bondholders as a whole. ${ }^{186}$ Comparatively, in a sovereign debt restructuring, the 'Uniformly Applicable' requirement inherent in aggregated CACs provides an expedient solution. This means that where an exchange offer is made, the bondholders must be offered the same menu: either prix fixe (fixed price) or a la carte. In either case, it is critical that the same offer must be available to all creditors. ${ }^{187}$ Moreover, if the proposal is to change the terms of the bonds, changes must be made across all affected series so that they become identical, thereby achieving the same outcome as if there had been an exchange offer. ${ }^{188}$ For example, the holder of a bond with a par value of $€ 100$ that matures in one year's time will be treated for voting and other purposes in the same way as the holder of a bond with a par value of $€ 100$ that matures in 30 years' time. ${ }^{189}$ Whilst in practice this would only affect a small number of very similar note issues that are being restructured, this requirement nevertheless

\footnotetext{
182 Zandstra (n 10) 187-8.

${ }^{183}$ International Monetary Fund (n 87) 18.

${ }^{184}$ ICMA, 'Sovereign Debt Restructuring - Recent Developments and Implications for the Fund's Legal and Policy Framework’ (April 2013) 30.

185 DeLong (n 29) 9.

${ }^{186}$ Simon James, 'ICMA Consults Further on Sovereign Bonds' (16 July 2014) Clifford Chance Briefing Note 2.

${ }^{187}$ Gelpern (n 172) 126.

188 James (n 186) 2.

189 ibid.
} 
has the effect of preserving inter-creditor equity and mitigating minority bondholder discrimination. ${ }^{190}$

However, the Uniformly Applicable measure (inherent in aggregated CACs) is further delimited by two instances: first, to the extent that the issuer wishes to offer different terms to different bond issuances; and second, when the issuer wishes to offer different terms to different groups of bond issuances. ${ }^{191}$ In addressing the first, the sovereign issuer may put one proposal forward to the holders of multiple series on the basis of single-limb voting and, at the same time, another proposal to the holders of one or more other series. ${ }^{192}$ For example, the holders of other series could be domestic banks and other noteholders. ${ }^{193}$ By structuring bondholder voting in this way, it would mitigate the sovereign from exposure to legal and financial risks — or in this example, the eventuality that requires the immediate recapitalization by the sovereign debtor (with the consequential financial drain impinging on all noteholders). ${ }^{194}$ This bolsters inter-creditor equity and increases the likelihood of achieving comprehensive and efficient restructuring.

Moreover, the flexibility prescribed by (two-limb or single-limb) aggregated CACs allows the sovereign to proceed on a sub-aggregate basis. ${ }^{195}$ Sovereigns remain free to structure bond issuances to allow for differentiation among creditors where appropriate. ${ }^{196}$ This is important in a complex debt restructuring that involves a multiplicity of bond issues with different features and economic interests. ${ }^{197}$ The objective is to create a complex set of voting pools of similar bonds that would receive different restructuring treatment. Similar bonds for example, all bonds denominated in the same currency, or all zero coupon bonds (bonds that pay no periodic interest payments and are sold at a heavy discount from face value) - could be placed in the same voting pool. ${ }^{198}$ Though the UN contends that this could resurrect internal fragmentation, and with it the possibility that financially powerful actors could gain a blocking

\footnotetext{
${ }^{190}$ Zandstra (n 10) 195.

191 ibid.

192 ibid.

193 ibid.

194 ibid.

195 ibid.

${ }^{196}$ IMF Policy Paper (n 87) 22.

${ }^{197}$ Martin Guzman and Joseph E Stiglitz, 'Creating a Framework for Sovereign Debt Restructuring that Works' Bonds' in Martin Guzman, José Antonio Ocampo and Joseph E Stiglitz (eds), Too Little, Too Late: The Quest to Resolve Sovereign Debt Crises (Columbia University Press 2016), 4-5.

198 ibid.
} 
minority, it is argued that structuring bond issues in this way would maximise the odds of a successful vote. ${ }^{199}$

Overall, the reformed CACs represent an important milestone in the debt restructuring sphere. The mechanisms used to obtain consent of bondholders go a long way in defusing the legal risk posed by holdouts, with the single-limb option seen as the most potent technique. As such, CACs (together with a revised pari passu clause) may be said to reflect a culmination of impressive collaboration between official sector, private sector, industry bodies and legal practitioners. ${ }^{200}$

\section{E. REFORM - A WAY FORWARD?}

Having discussed the role of contractual terms in framing the enforcement of creditor rights (rendered the more potent in the absence of an international legal framework to deal with a universe of claims from different types of creditors), this Section examines market participants' reform proposals and provides independent judgment as to how best to fill this area of law. ${ }^{201}$ The current decentralised system for restructuring sovereign debt lacks the statutory tools needed to address market dislocations. Notwithstanding the recent contractual reforms, the present system still fails to comprehensively resolve debt crises and equitably enforce creditor rights. ${ }^{202}$ The current framework relies upon a complex set of negotiations that include many creditors, with different interests, often under the backdrop of complex national legal regimes; this is deeply problematic and leads to ex-ante and ex-post inefficiencies, and inequities both among creditors and between the debtor and its creditors. ${ }^{203}$ In addressing these problems, market participants have promulgated a variety of solutions that include: the introduction of new contractual provisions into new external debt contracts; the development of a code of conduct for a sovereign to follow during a debt restructuring; and the creation of a new statutory regime to provide bankruptcy-style protection for a sovereign. ${ }^{204}$

\footnotetext{
199 ibid; UNCTAD, 'Sovereign Debt Workouts: Going Forward: Roadmap and Guide' (April 2015) 46.

${ }^{200}$ Zandstra (n 10) 180.

${ }^{201}$ Rodrigo Olivares-Caminal, 'The Definition of Indebtedness and the Consequent Imperilling of the Pari Passu, Negative Pledge and Cross-default Clauses in Sovereign Debt Instruments' (2017) 12(2) Capital Markets Law Journal 164.

${ }^{202}$ Martin Guzman and Joseph E Stiglitz, 'A Soft Law Mechanism for Sovereign Debt Restructuring' (October 2016) Friedrich Ebert Stiftung 3; Stephen Park and Tim Samples, 'Tribunalizing Sovereign Debt: Argentina's Experience with Investor-State Dispute Settlement' (2017) 50(4) Vanderbilt Journal of Transnational Law 1033, 1059.

${ }^{203}$ Martin Guzman and Joseph E Stiglitz (n 197) 4.

${ }^{204}$ Nouriel Roubini and Brad Setser, 'Improving the Sovereign Debt Restructuring Process: Problems in Restructuring, Proposed Solutions, and a Roadmap for Reform' (9 March 2003) Peterson Institute for International Economics 8.
} 
This paper advocates for a dual-pronged approach based on a Model Law system. The first prong consists of formalising the norms in the twinned UN Resolution(s) and ensuring the proper resolution of sovereign debt crises moving forward. ${ }^{205}$ It would do so by building incremental steps towards the development of norms; this would create a legal framework that places itself suitably between the 'soft' and 'hard' law approaches. The (proposed) regime would be predicated on national governments internalising the 'Model Law' in their jurisdiction via legislation. ${ }^{206}$ Whilst this approach relies on uniform enactment - given that the claims of holdout creditors would be governed by the law of a jurisdiction that enacts the Model Law, this route would serve to both enforce creditor rights, which is desirable from the perspective of efficient debt markets, and avoid the holdout creditor problem, which is desirable from the perspective of an efficient resolution of debt crises. ${ }^{207}$

Guzman and Stiglitz partly concur, positing that whilst CACs are insufficient to address the deficiencies of the current system, ${ }^{208}$ a soft law approach based upon the UN Principles ${ }^{209}$ would create a regime that would promote further cooperation and creditor coordination. The recognition of these principles, they argue, would contribute to the speedy and orderly resolution of debt.

However, it is argued that the UN Principles, ${ }^{210}$ though persuasive, lack the granularity that is desirable to ensure legal certainty. ${ }^{211}$ Rather than confront states immediately with a legal regime akin to the SDRM, states should progressively be led toward stronger legal rules. ${ }^{212}$ This would mitigate any sovereignty considerations (a key drawback for the SDRM) and would be a more effective way of restructuring sovereign debt than a purely financial framework of preventing an unbounded accumulation of debts. ${ }^{213}$ What makes the dual-

\footnotetext{
${ }^{205}$ Oona A Hathaway, 'Between Power and Principle: An Integrated Theory of International Law' (2005) 72(2) The University of Chicago Law Review 469.

${ }^{206}$ Steven L Schwarcz, 'A Model-Law Approach to Sovereign Debt Restructuring' (2017) 50 Duke Law School Public Law \& Legal Theory Series 4-5.

${ }^{207}$ Federico Sturzenegger and Jeromin Zettelmeyer, Debt Defaults and Lessons from a Decade of Crises (The MIT Press 2007) 76.

${ }^{208}$ Guzman (n 203) 1. See also James A Haley, 'Sovereign Debt Restructuring: Bargaining for Resolution' (April 2017) 124 CIGI Papers 7.

${ }^{209}$ General Assembly of the United Nations, 'Basic Principles on Sovereign Debt Restructuring Processes' (10 September 2015) Resolution No A/RES/69/319.

210 ibid; General Assembly of the United Nations, 'Towards the Establishment of a Multilateral Legal Framework for Sovereign Debt Restructuring Processes’ (9 September 2014) Resolution No A/RES/68/304, 4.

${ }^{211}$ Matthias Goldmann, 'Putting your Faith in Good Faith: A Principled Strategy for Smoother Sovereign Debt Workouts' (2016) 41(2) Yale Journal of International Law 117, 140.

${ }^{212}$ Hathaway (n 205) 531.

${ }^{213}$ Maximo Paulino T Sison III, 'Sustainability in Indebtedness: A Proposal for a Treaty-Based Framework in Sovereign Debt Restructuring’ (2018) $11<$ https://www.intechopen.com/books/accounting-and-finance-new-
} 
pronged approach distinctly attractive is the potential for these norms to have (enforcement) teeth; initially, this can only be done if the norms are broad enough so as to provide states with much needed flexibility to adopt specific measures in resolving debt crises. ${ }^{214}$ This would set the foundation for more concrete 'hard law' debt restructuring measures in the future. ${ }^{215}$

The second prong comprises of a Sovereign Debt Forum. ${ }^{216}$ This would bring together leading pioneers in this area of law under one umbrella, lobbying both relevant participants in markets and the official sector for meaningful change, and provide expert legal assistance on request. This is attractive in practice; by compiling lessons from past sovereign debt treatments to continually refine existing approaches to sovereign debt treatment, it would help to make sovereigns' and creditors' processes more predictable, credible and more likely to succeed, thereby increasing the incentive to deal with debt problems expeditiously. ${ }^{217}$ Given the IMF's recent discontinuation of annual progress reports, creating a forum that continues to enrich the repository of sovereign debt data seems a plausible one. ${ }^{218}$

It is clear that incremental reform is the order of the day: an institutional setup can only be achieved through the lens of soft law progression. This is central to the codification idea and would represent a significant advancement towards a multilateral normative framework. ${ }^{219}$ In the event that the treaty-based approach fails, the soft law approach of a knowledge-based Forum would (at least) act as a backstop in promoting further collaboration and build incremental steps towards devising a reliable debt restructuring framework.

\section{F. CONCLUSION}

The history of corporate bonds suggests that if sovereign defaults are sufficiently painful and protracted, procedures to create greater order will eventually be developed. ${ }^{220}$ The adoption of the revised pari passu and CACs with robust aggregation features are two such tools, aiming to address market dislocations that beset sovereign debt restructurings. ${ }^{221}$ This paper has

\footnotetext{
perspectives-on-banking-financial-statements-and-reporting/sustainability-in-indebtedness-a-proposal-for-atreaty-based-framework-in-sovereign-debt-restructuri> accessed 11 April 2020.

214 ibid.

215 ibid 7.

${ }^{216}$ Wood (n 4) 21.

${ }^{217}$ Richard Gitlin and Brett House, ‘A Blueprint for a Sovereign Debt Forum' (12 March 2014) 27 CIGI Papers 15.

${ }^{218}$ International Monetary Fund, 'Fourth Progress Report on Inclusion of Enhanced Contractual Provisions in International Sovereign Bond Contracts' (Washington DC, 21 March 2019); Wood (n 4) 21.

${ }^{219}$ Sison (n 213).

${ }^{220}$ Group of Thirty, 'Key Issues in Sovereign Debt Restructuring: A Working Group Report' (Washington DC, 2002).

${ }^{221}$ Deborah Zandstra, 'Creditor Engagement in Sovereign Debt Restructurings' (6 April 2016) Clifford Chance Briefing Note.
} 
explored how the contractual provisions in sovereign bond contracts have sought to fill the restructuring void. It has examined how they provide much needed flexibility to sovereigns wishing to restructure their debts while at the same time providing robust protection to noteholders through the procedures and majorities required in order to restructure those debts. ${ }^{222}$ It has also proven that consent and cooperation are more important than ever - unlike in corporate debt restructurings, which take their shape through a formal bankruptcy process.

The controversial interpretation of the pari passu clause, engendered by holdout litigation underlines the chasm and complex enigma surrounding the precise scope of the clause - with the rateable payment interpretation being analogous to 'the green-eyed monster which doth mock/The meat it feeds on'. ${ }^{223}$ Such interpretation has, however, been contemporarily constricted by the ratio in White Hawthorn ${ }^{224}$ and the revised pari passu clause. CACs have been long said to facilitate orderly debt restructurings by diluting the power of obdurate creditors and restoring it to the body of creditors as a whole. ${ }^{225}$ By providing a wider relief menu and flexibility to sovereign debtors, CACs encourage holdouts to join a negotiated consensual restructuring of the sovereign's debt, thereby allowing for a more efficient and equitable sovereign debt restructuring process. In the European context, Euro CACs may be seen as a primary tool of resolving collective action problems, deriving its standardised application from the ESM Treaty. Nevertheless, involuntary mechanisms must not be discounted and still remain (albeit as a last resort) ${ }^{226}$ on the restructuring table. On the issue of reform, whilst the UN Principles are not enough to create a binding normative framework, this paper recommends a two-pronged approach of multilateralism based upon the broad codification of UN Principles as a next step in the evolution of this field. This would be complementary to the existing debt restructuring framework and would build upon the existing 'soft law' approaches and practices that underpin sovereign debt restructurings.

Aggregated CACs are the way forward in minimising the holdout threat and there is no doubt that their wholesale adoption would be a significant development in harmonising market practice around the world. ${ }^{227}$ The revised pari passu clause also goes some way in constricting the collective action problem by expressly disavowing the much-loathed rateable

\footnotetext{
222 James (n 186) 2.

${ }^{223}$ Buchheit, 'Restructuring Sovereign Debt after NML v Argentina' (n 39) 224.

${ }^{224}$ White Hawthorne (n 44).

225 Stolper (n 37) 241; DeLong (n 29) 14.

${ }^{226}$ Buchheit, 'Use of the Local Law Advantage in the Restructuring of European Sovereign Bonds' (n 152) 5.

${ }^{227}$ International Monetary Fund (n 218) 10.
} 
interpretation. Viewed in this light, it is argued that whilst the enhanced contractual provisions are not a panacea, they collectively represent a substantial step forward and provide a 'meaningful enhancement of the plumbing of the international financial architecture'. ${ }^{228}$

A message to Argentina and Lebanon -and any other country that is in default or whose future hinges upon the immediacy of a default: despite the much-lauded reforms, the 'Great Game,229 continues...

${ }^{228}$ Sobel, 'Strengthening Collective Action Clauses: Catalysing Change - the Back Story' (2016) 11(1) Capital Markets Law Journal 3, 11.

${ }^{229} \mathrm{Crabb}$ (n 3). 